\title{
Induced spawning and reproductive variables of the catfish Lophiosilurus alexandri Steindachner, 1876 (Siluriformes: Pseudopimelodidae)
}

\author{
Hélio Batista dos Santos ${ }^{1}$, Edson Vieira Sampaio², Fábio Pereira Arantes ${ }^{3}$ \\ and Yoshimi Sato ${ }^{2}$
}

Lophiosilurus alexandri is an endemic fish from the São Francisco River basin, Brazil. The aim of this study was to induce L. alexandri to spawn and to obtain data on several reproductive variables for this species. For induced spawning, adults were submitted to Cyprinus carpio pituitary homogenate (CPH). Nine of the 12 females $(75 \%)$ responded positively to the treatment. The stripping of oocytes was performed $8.4 \mathrm{~h}$ after the second dose of $\mathrm{CPH}$ with the water temperature maintained at $26^{\circ} \mathrm{C}$. The number of stripped oocytes per gram of ova was $74 \pm 5$ oocytes g-1 and the mean oocyte diameter was $3.1 \pm 0.2$ and $3.6 \pm 0.2 \mathrm{~mm}$, before and after hydration, respectively. The oocytes were opaque, yellowish, demersal, highly adhesive, and covered by a gelatinous coat. The total fecundity was $4,534 \pm 671$ oocytes, and the fertilization rate was $59 \%$. The initial and final fertilities were 2,631 \pm 740 and 1,542 \pm 416 embryos, respectively. Larval hatching occurred up to $56 \mathrm{~h}$ after fertilization, and the larvae had a total length of $8.4 \pm 0.1 \mathrm{~mm}$. This work provides important biological information for $L$. alexandri that can be used for management and conservation of this species.

Lophiosilurus alexandri é um peixe endêmico da bacia do rio São Francisco, Brasil. O objetivo do trabalho foi induzir $L$. alexandri à desova e obter dados sobre várias variáveis reprodutivas para esta espécie. Para desova induzida, adultos foram submetidos ao homogeneizado de hipófise de Cyprinus carpio (HHC). Nove das 12 fêmeas (75\%) responderam positivamente ao tratamento. A extrusão dos ovócitos aconteceu $8,4 \mathrm{~h}$ após a segunda dose de $\mathrm{HHC}$ com a temperatura da água mantida a $26^{\circ} \mathrm{C}$. O número de ovócitos liberados por grama de ova foi de $74 \pm 5$ ovócitos $\mathrm{g}^{-1} \mathrm{e}$ a média do diâmetro ovocitário foi de 3,1 $\pm 0,2$ e 3,6 0,2 $\mathrm{mm}$, antes e depois da hidratação, respectivamente. Os ovócitos foram opacos, amarelo-castanho, demersais, altamente adesivos e revestidos por capa gelatinosa. A fecundidade total apresentou $4.534 \pm 671$ ovócitos e a taxa de fertilização foi de 59\%. As fertilidades inicial e final foram de $2.631 \pm 740$ e $1.542 \pm 416$ embriões, respectivamente. A eclosão das larvas aconteceu até $56 \mathrm{~h}$ após a fertilização e as larvas tiveram comprimento total de $8,4 \pm 0,1 \mathrm{~mm}$. Este trabalho fornece informações biológicas importantes para L. alexandri, que podem ser utilizadas para o manejo e conservação desta espécie.

Key words: Artificial reproduction, Fecundity, Fertility, Hypophysation assay, Neotropical catfish.

\section{Introduction}

The Siluriformes constitutes a teleost group of 37 families with 3569 species described (Eschemeyer \& Fong, 2013) The majority of the species from this order occur mainly in tropical regions such as South America, Africa, and Southeast Asia (de Pinna, 1998). Pseudopimelodidae is a family of freshwater Neotropical catfish representing
37 species that are restricted to South America (Eschemeyer \& Fong, 2013). Lophiosilurus alexandri Steindachner, 1876 , is popularly known as "pacamã" and is a member of the Pseudopimelodidae that is endemic to the São Francisco River basin. It is a sedentary and piscivorous fish that preferentially inhabits lentic environments, with the males exhibiting parental care. Lophiosilurus alexandri reaches gonadal maturation from October to February, coinciding

\footnotetext{
${ }^{1}$ Universidade Federal de São João Del Rei, Câmpus Ciências e Saúde. Av. Sebastião Gonçalves Coelho, 400, Chanadour, $35501-296$ Divinópolis, Minas Gerais, Brazil.hbsufsj@gmail.com

${ }^{2}$ Estação de Hidrobiologia e Piscicultura de Três Marias, CODEVASF, Minas Gerais, Brazil.

${ }^{3}$ Pontifícia Universidade Católica de Minas Gerais, Programa de Pós-Graduação em Zoologia de Vertebrados, Minas Gerais, Brazil.
} 
with the local rainy season (Sato et al., 2003a, 2003b). This fish is very important in sport and craft fishing because it reaches up to $8 \mathrm{~kg}$ in body weight (Sato et al., 2003a). Moreover, it has economic potential in aquaculture due to its fillet quality, market price, and international use in ornamental aquaria (Santos \& Luz, 2009).

Natural fish populations have declined over the last several decades because of environmental degradation and overfishing. This has resulted in an increased effort to develop techniques for hatchery production of fish. The hypophysation has been used for induction and synchronization of ovulation and spawning in several species of fish in captivity (Woynarovich \& Horvat, 1980; Sato et al., 1999; Sato et al., 2003a; Sampaio \& Sato, 2006; Nogueira et al., 2012; Santos et al., 2013). Moreover, data on reproductive variables, such as fecundity and fertility, can be obtained from induced spawning; such variables are needed for species conservation and efficient production of embryos, larvae, and fingerlings.

The number of oocytes eventually released by an individual during its breeding period is considered total fecundity. The relative fecundity, calculated in relation to body weight or length, is indicative of the reproductive capacity (Arantes et al., 2011). Therefore, fecundity studies are important for the successful management and conservation of fish stocks (Shatunovskiy, 1988; Arantes et al. , 2011). Another biologically important variable is fertility, which is of practical importance in hatcheries. Initial fertility indicates the number of stripped eggs, while final fertility is the number of viable embryonic eggs estimated after blastopore closure (Sato et al., 2000; Sato et al., 2003a, 2003b; Sampaio \& Sato, 2006). Knowledge of the fecundity and fertility of a particular species is an important tool that can be applied in aquaculture and fish farming.

Because biological information about artificial reproduction and other reproductive aspects of $L$. alexandri is limited, the goal of this work is to induce spawning by hypophysation and to describe the reproductive variables of $L$. alexandri. This will provide essential data that can be subsequently applied to the management, conservation, and aquaculture of this species.

\section{Material and Methods}

Breeding management. All experiments were performed at the Hydrobiology and Hatchery Station of Três Marias $\left(18^{\circ} 11^{\prime} 58^{\prime}\right.$ 'S $\left.45^{\circ} 15^{\prime} 07^{\prime \prime} \mathrm{W}\right)$, Minas Gerais, Brazil, in accordance with the Guidelines for Animal Experimentation established by the Brazilian College for Animal Experimentation (COBEA). Adult specimens of L. alexandri were captured in the São Francisco River and kept for at least one year in a $600-\mathrm{m}^{2}$ pond at a stocking rate of $1 \mathrm{~kg}$ of fish per $5 \mathrm{~m}^{2}$. The experiment was performed in January 1997, and the animals were fed, ad libitum, live fish such as tilapia Oreochromis niloticus and curimatãs Prochilodus argenteus. A voucher specimen was deposited in the Museu de Zoologia of the Universidade de São Paulo (MZUSP 105894).

Breeding selection for induced reproduction was performed using secondary sex characters of females and males observed in reproduction. Then, animals selected were transferred to treatment tanks $(3 \times 1 \times 0.8 \mathrm{~m})$. The tanks were supplied with running water having the following physical characteristics that were maintained throughout the experiment: temperature $=26^{\circ} \mathrm{C}$, dissolved oxygen $=$ $5.9-6.2 \mathrm{mg} \mathrm{L}^{-1}$, conductivity $=58-65 \mu \mathrm{S} \mathrm{cm}^{-1}$, and $\mathrm{pH}=6.8-$ 7.2. The rate of water flow in the tanks was approximately $15 \mathrm{~L} \mathrm{~min}^{-1}$.

Induced spawning. For the hypophysation experiment, twenty-four specimens (males and females) of $L$. alexandri were induced to spawn with crude extract of Cyprinus carpio pituitary. The carp pituitary homogenate $(\mathrm{CPH})$ was prepared by macerating dried pituitaries (Agrober, Budapest, Hungary) in glycerin followed by homogenization in physiological saline $(0.7 \% \mathrm{NaCl})$. The females that presented bulging of the coelomic cavity and urogenital papilla reddish received two intraperitoneal injections of $\mathrm{CPH}\left(0.8 \pm 0.2\right.$ and $6.0 \pm 0.6 \mathrm{mg} \mathrm{kg}^{-1}$ body weight $)$ with a 14 $\mathrm{h}$ interval between injections. The males received a single dose containing $2.4 \pm 0.2 \mathrm{mg} \mathrm{kg}^{-1}$ body weight of the same $\mathrm{CPH}$ at the time that the second dose was given to the females (Woynarovich \& Horvat, 1980; Sato et al., 2003a). The water temperature of the tank was measured every hour after the second dose of hormone to calculate the degree-hours (average water temperature $\mathrm{x}$ number of hours until spawning) and to estimate the time of spawning in $L$. alexandri.

Fecundity, fertilization rate, fertility, and hatching. For the purpose of estimating the total fecundity, samples of spawned oocytes were collected and weighed. Total fecundity was determined considering the total number of oocytes (stripped oocytes plus released oocytes and oocytes retained in the ovaries). The number of oocytes per gram of ova was obtained by counting fresh oocytes present in approximately $2 \mathrm{~g}$ of ova samples. Additionally, the stripped ova index was calculated using the following formula (SOI $=100 \mathrm{x}$ stripped ova weight $\mathrm{x} \mathrm{BW} \mathrm{BW}^{-1}$ where $\mathrm{BW}$ = body weight). After stripping, the animals were killed by transversal section of the spinal cord, and for each female, the gonadosomatic index was also calculated (GSI $=100 \mathrm{x}$ $\mathrm{GW} \mathrm{x} \mathrm{BW}^{-1}$, where $\mathrm{GW}=$ weight of free oocytes released + weight of ovaries after extruded).

The oocytes and sperm were obtained by stripping, and dry fertilization was performed (Sato et al., 2003a). After fertilization, $20 \mathrm{~g}$ of fertilized eggs of each female was rinsed with water to allow hydration, and then the embryos were transferred to funnel-type fiberglass incubators with 20 L capacity (Woynarovich \& Horvat, 1980). The water supplying the incubators had the following 
physicochemical characteristics: temperature $=23.0-25.0^{\circ} \mathrm{C}$, dissolved oxygen $=5.9-6.2 \mathrm{mg} \mathrm{L}^{-1}, \mathrm{pH}=6.8-7.2$ and conductivity $=58-65 \mu \mathrm{S} \mathrm{cm}^{-1}$. For each female that responded to induced spawning, the fertilization rate of the eggs (i.e., relative number of viable and dead embryos) was calculated from a sample of 200 eggs after blastopore closure, which were collected from the middle section of the incubator. For each female that responded to induced spawning, the initial fertility (the number of stripped eggs) and the final fertility (the number of viable embryonic eggs counted after blastopore closure, Sato et al., 2000) were determined using 200 eggs, which were collected from the middle section of the incubator with a glass tube. Finally, a linear relationship of total fecundity, initial and final fertility in relation to body weight or total length was determined for L. alexandri.

The number of degree-hours for hatching was calculated using the average incubator water temperature (recorded every hour) multiplied by the time period spanning the moment the hydrated eggs were dropped into the incubator until hatching.

Morphology and morphometry. The morphology of the ovaries and testes were recorded for L. alexandri. After spawning, the animals were killed, and the gonads were removed. For histology, ovary and testis samples were fixed in Bouin's solution for $6-8 \mathrm{~h}$ at room temperature. The specimens were embedded in paraffin, sectioned at a thickness of 3-5 $\mu \mathrm{m}$, and stained with hematoxylin-eosin (Michalany, 1980).

Twenty eggs for each female (non-hydrated and hydrated) were used to measure the vitelline sac diameter, perivitellinic space width, and chorion thickness using an ocular micrometer coupled to an Olympus stereomicroscope. Egg pigment and the presence or absence of a gelatinous coat were also described. The total length $(\mathrm{mm})$ of newly hatched larvae was measured using 180 specimens (i.e., 20 larvae from each incubator). The presence or absence of a larval adhesive organ was also determined using a stereomicroscope, and the initial larval displacement in the water column was also recorded.

Statistical analyses. Descriptive statistics and linear regression for biological variables such as total fecundity, initial and final fertility, total length, and body weight were performed using GraphPad InStat (Software Inc., Version 3.05, San Diego, CA, USA), and the values were expressed as the means \pm standard deviation (SD).

\section{Results}

The females did not differ in size from males, but when abdominal pressure was applied, the females released oocytes whereas for the males, semen was obtained with difficulty. Ten males (Table 1) responded positively to hypophysation (i.e., approximately $83 \%$ ); they were easily
Table 1. Means, standard deviation and range of the total length (TL), body weight (BW) and animals number (N) of Lophiosilurus alexandri that responded to induced spawning.

\begin{tabular}{ccccc}
\hline & \multicolumn{2}{c}{ Females $(\mathrm{N}=9)$} & \multicolumn{2}{c}{ Males $(\mathrm{N}=10)$} \\
\cline { 2 - 5 } & Mean \pm SD & Range & Mean \pm SD & Range \\
\hline TL $(\mathrm{cm})$ & $62.7 \pm 2.4$ & $57.0-70.0$ & $61.9 \pm 4.0$ & $56.0-67.0$ \\
BW $(\mathrm{kg})$ & $3.2 \pm 0.9$ & $2.2-4.8$ & $2.7 \pm 0.5$ & $2.1-3.8$ \\
\hline
\end{tabular}

handled, and secondary sex characters such as emission sounds were not observed while they were kept in the experimental tanks. Nine females (Table 1) responded positively to hypophysation (i.e., 75\%).

Reproductive variables. Data on biological variables such as the mean number of oocytes per gram of ova, the stripped ova index, the gonadosomatic index, fertilization rate, total fecundity, and initial and final fertility after induced spawning in L. alexandri are listed in Table 2. Ovulation occurred approximately 8.1-8.7 $\mathrm{h}$ after the second dose of $\mathrm{CPH}$ at $26^{\circ} \mathrm{C}$, corresponding to $210-225$ degree-hours $(218 \pm 6)$. The linear relationship showed that total fecundity, initial fertility, and final fertility increase proportionally with body weight and total length in L. alexandri (Fig. 1).

Egg biology. The eggs of $L$. alexandri were opaque, light yellow, demersal, adhesive and covered with a gelatinous coat. After fresh stripping, the non-hydrated oocyte diameter was approximately $3.0 \mathrm{~mm}$ and increased to $3.5 \mathrm{~mm}$ after hydration. Other findings about the egg biology of $L$. alexandri such as perivitellinic space width, chorion thickness and yolk sac diameter are summarized in Table 3.

Gonad morphology. Macroscopically, L. alexandri ovaries and testes were paired organs, and the ovarian ducts opened into the urogenital papilla. The mature ovaries were bulky, highly vascularized, and yellowish and had large vitellogenic oocytes that were observable macroscopically

Table 2. Means of the oocytes number per gram of ova, stripped ova index, gonadosomatic index, fertilization rate, total fecundity, and initial and final fertility after induced spawning in females of Lophiosilurus alexandri $(\mathrm{N}=9)$.

\begin{tabular}{lcc}
\hline \multicolumn{1}{c}{ Variables } & Mean \pm SD & Range \\
\hline Oocytes number per gram of ova & $74 \pm 5$ & $68-81$ \\
Stripped ova index (\%) & $1.2 \pm 0.2$ & $0.9-1.4$ \\
Gonadosomatic index (\%) & $2.0 \pm 0.4$ & $1.6-2.9$ \\
Egg fertilization rate (\%) & $59 \pm 5$ & $51.8-68.4$ \\
Total fecundity & $4,534 \pm 671$ & $3,519-5,467$ \\
Initial fertility & $2,631 \pm 740$ & $1,501-3,920$ \\
Final fertility & $1,542 \pm 416$ & $898-2241$ \\
\hline
\end{tabular}



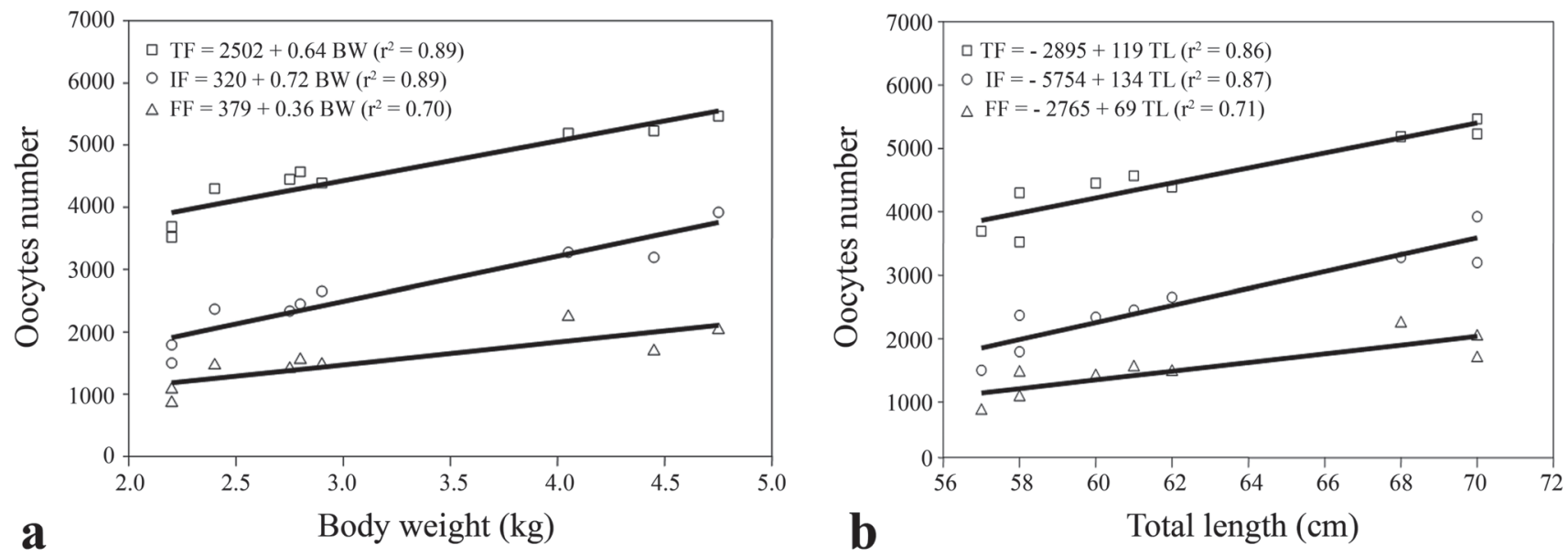

Fig. 1. Linear relationships of total fecundity (TF), initial fertility (IF) and final fertility (FF) to variations in body weight (BW) (a) and total length (TL) (b), obtained simultaneously from nine Lophiosilurus alexandri females submitted to hypophysation at Três Marias Hydrobiology and Hatchery Station in January 1997.

(Fig. 2a). Microscopically, the mature ovaries mainly exhibited vitellogenic oocytes, which contained acidophilic yolk globules that were widespread throughout the ooplasm (Fig. 2b). Mature testes were whitish, voluminous, turgid, and highly vascularized and had well developed fringes (Fig. 2c). The histological analyses of the mature fringed testis showed seminiferous tubules filled with sperm (Fig. 2d).

The larvae of Lophiosilurus alexandri. Hatching time ranged from $54.8-58.0 \mathrm{~h}$ at $24^{\circ} \mathrm{C}$, corresponding to 1,260 1,450 degree-hours $(1,358 \pm 60)$. The larvae of $L$. alexandri had no adhesive organs and an absence of vertical movements in the water column. The newly hatched larvae had an average total length of $8.4 \pm 0.1 \mathrm{~mm}$.

Table 3. Means of the non-hydrated and hydrated oocytes diameter, yolk sac diameter, perivitellinic space width and chorion thickness after induced spawning in females of Lophiosilurus alexandri $(\mathrm{N}=180)$.

\begin{tabular}{lcc}
\hline \multicolumn{1}{c}{ Egg measurements } & Mean \pm SD & Range \\
\hline Non-hydrated oocytes diameter & $3.1 \pm 0.2 \mathrm{~mm}$ & $2.8-3.3 \mathrm{~mm}$ \\
Hydrated oocytes diameter & $3.6 \pm 0.2 \mathrm{~mm}$ & $3.3-3.8 \mathrm{~mm}$ \\
Yolk sac diameter & $2.7 \pm 0.1 \mathrm{~mm}$ & $2.4-2.9 \mathrm{~mm}$ \\
Perivitellinic space width & $0.2 \pm 0.02 \mathrm{~mm}$ & $0.1-0.3 \mathrm{~mm}$ \\
Chorion thickness & $0.3 \pm 0.01 \mathrm{~mm}$ & $0.25-0.29 \mathrm{~mm}$ \\
\hline
\end{tabular}

\section{Discussion}

This manuscript provides important biological data regarding artificial reproduction and reproductive variables of pacamã L. alexandri, an endemic fish from the São Francisco River basin with great economic potential for aquaculture and for restocking operations. Essential biological information about wild populations, such as reproductive cycles, fecundity, and fertility, are needed to manage native and endangered species and for aquaculture purposes (Sato et al., 1998; Sato et al., 2003a; Caneppele et al., 2009; Arantes et al., 2011). Although L. alexandri is potentially useful in aquaculture and important in sport and craft fishing, only a few studies about its reproductive biology have been published, and they describe the reproductive apparatus, gametogenesis, and adhesive eggs (Rizzo et al., 2002; Barros et al., 2007). In the present study, L. alexandri responded well to treatment with $\mathrm{CPH}$; the rate of positive responses in females submitted to hypophysation $(75 \%)$ was high compared to other Siluriformes species: $58.3 \%$ in Pseudoplatystoma corruscans (Sato et al., 2003a) and 67\% in Trachelyopterus galeatus (Santos et al., 2013), or was similar to 70.4\% in Pimelodus maculatus (Sato et al., 1999), $71 \%$ in Rhamdia sapo (= Rhamdia quelen) (Espinach Ros et al., 1984), $75 \%$ in Pseudopimelodus charus, and $80 \%$ in R. quelen (Sampaio \& Sato, 2006). Induced spawning by hypophysation has been used with success in several migratory and sedentary fish from the São Francisco River basin (Sato et al., 2003a). These studies of artificial reproduction are important for gaining knowledge of reproductive variables, embryogenesis, and larval and fingerling 

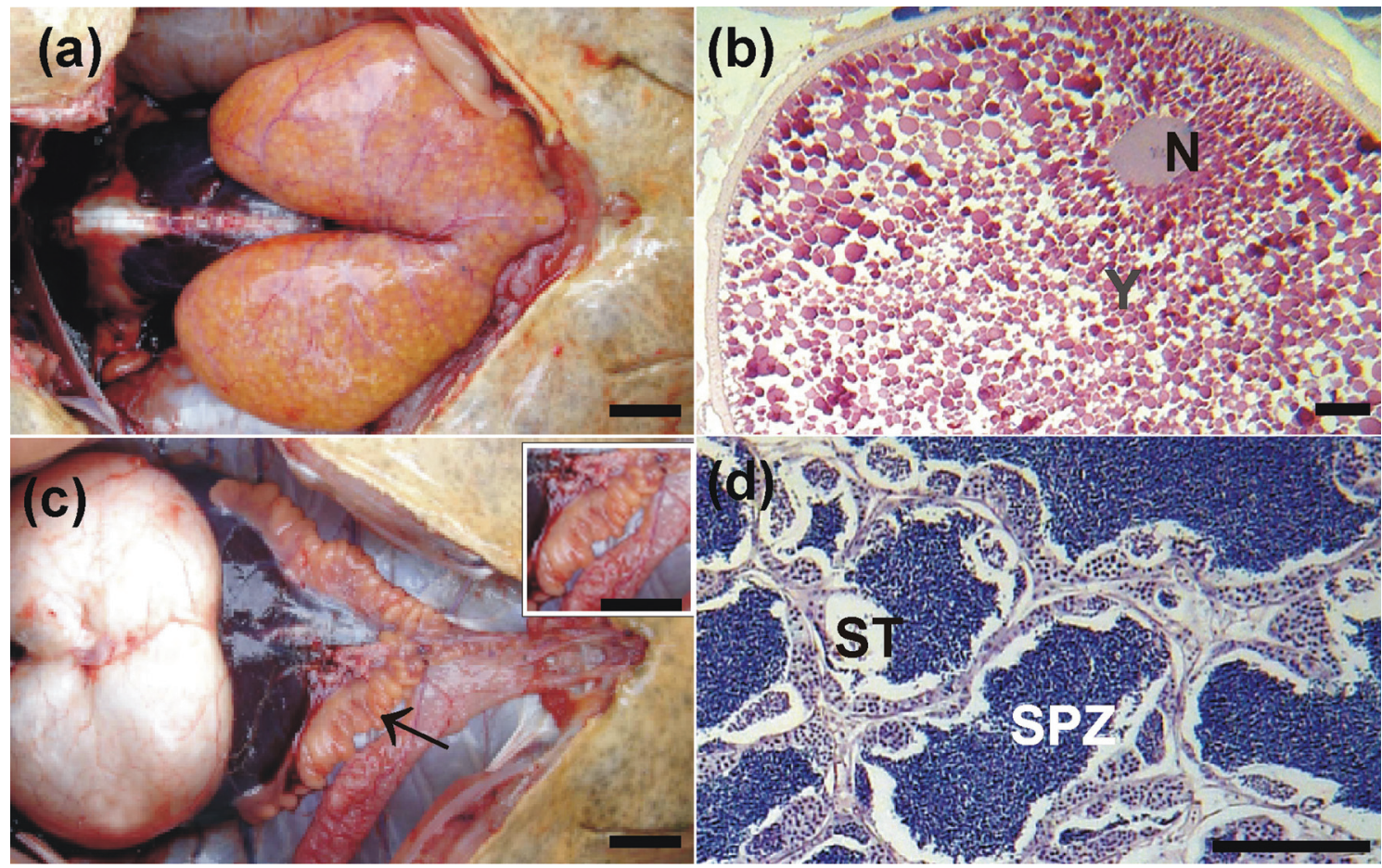

Fig. 2. Macro and microscopic morphology of the ovaries (a-b) and testis (c-d) mature of the Lophiosilurus alexandri. (a) The mature ovaries were bulky, highly vascularized, yellowish and presenting large vitellogenic oocytes. (b) Histological section of the vitellogenic oocyte characterized by the presence of acidophilic yolk globules (Y) throughout the ooplasm and nucleus (N) migrating toward the animal pole. (c) Mature testis (arrow) are whitish, turgids, vascularized and with well developed fringes (Insert showing fringes). (d) Mature testis showing seminiferous tubules (ST) filled by spermatozoa (SPZ). (a, c and insert) bars $1 \mathrm{~cm}$; (b and d) stained with hemotoxylin-eosin and bars $100 \mu \mathrm{m}$.

development of these species in aquaculture at the Três Marias hatcheries, Minas Gerais, Brazil (Sato et al., 2003a).

The relationship between temperature and time can be expressed in degree-hours that is used in several fields, including agriculture and meteorology, for to predict temperature dependent processes. In fish farming, the concept of degree-hours is a valuable tool for estimating the time of ovulation and hatching because temperature is an important abiotic factor that influences the speed of physiological processes of organisms. The stripping of the oocytes from $L$. alexandri was performed at an average of 218 degree-hours (approximately $8.4 \mathrm{~h}$ ) after the second dose of $\mathrm{CPH}$ at $26^{\circ} \mathrm{C}$; these results were similar to those obtained in other Siluriformes submitted to the same water temperature: 212 degree-hours in Rhinelepis aspera (Sato et al., 1998), 213 in Pimelodus maculatus (Sato et al., 1999), and 226 in Pseudoplatystoma corruscans (Sato et al., 2003a). Hatching in L. alexandri was on average 1358 degree-hours (approximately $56.6 \mathrm{~h}$ ) after egg fertilization at $24^{\circ} \mathrm{C}$, which is a relatively long time but is similar to that of other Siluriformes that have adhesive and large eggs:
1099 degree-hours (approximately 45.8 h) in Franciscodoras marmoratus and 1022 degree-hours (approximately $42.6 \mathrm{~h}$ ) in Rhinelepis aspera (Sato et al., 2003a). However, in Siluriformes with free eggs, the hatching period is shorter: $27 \mathrm{~h}$ at $23^{\circ} \mathrm{C}$ in Rhamdia hilarii ( $=$ R. quelen) (Godinho et al., 1978); $30-45 \mathrm{~h}$ at $22-24{ }^{\circ} \mathrm{C}$ in $R$. sapo (=R. quelen) (Cussac et al., 1985); $30.5 \mathrm{~h}$ at $24^{\circ} \mathrm{C}$ in $R$. quelen (Riehl \& Patzner, 1998); $16.2 \mathrm{~h}$ at $24.2^{\circ} \mathrm{C}$ in Pimelodus maculatus (Sato et al., 1999); and $20 \mathrm{~h}$ at $24.4^{\circ} \mathrm{C}$ in Pseudoplatystoma corruscans (Sato et al., 2003a).

Lophiosilurus alexandri had spherical, opaque, demersal, yellowish eggs that had a gelatinous coat and great adhesiveness, which are properties that have also been reported in several Siluriformes species (Godinho et al., 1978; Espinach Ros et al., 1984; Sato et al., 2003b; Santos et al., 2013). The presence of a gelatinous coat appears to be a common feature in Siluriformes eggs (Pereira et al., 2006). The gelatinous coat provides the eggs the ability to bind to submerged vegetation or objects as well as other eggs (Riehl \& Patzner, 1998). However, there are eggs that have a gelatinous coat without adhesiveness as described 
for Pseudoplatystoma corruscans, Pseudopimelodus charus, R. quelen, and Pimelodus maculatus (Sato et al., 2003a). Non-hydrated eggs of L. alexandri measured on average $3.1 \mathrm{~mm}$ and after hydration this increased to 3.6 $\mathrm{mm}$, an increase of approximately $16 \%$, which can be considered small compared to eggs from other Siluriformes species (Sato et al., 2003b) and high compared to the egg diameter after hydration in the reared catfish Zungaro jahu (Nogueira et al., 2012).

The gonad morphology of $L$. alexandri was similar to those described for pacamã from the Santo Antônio River, Minas Gerais, Doce River basin (Barros et al., 2007). However, in the present study, histological ovary sections from the females that were induced to spawn had vitellogenic oocytes exhibiting nucleus migration toward the mycropilar apparatus in the region of the animal pole. This cellular event is a feature of final maturation, and it was also recorded in vitellogenic oocytes of Prochilodus argenteus submitted to CPH (Arantes et al., 2011). Morphometric data regarding the perivitellinic space width (approximately 190 $\mu \mathrm{m}$ ), yolk sac diameter (approximately $2650 \mu \mathrm{m}$ ), and chorion thickness (approximately $270 \mu \mathrm{m}$ ) were obtained for $L$. alexandri. The chorion thickness in newly fertilized eggs of $L$. alexandri was relatively larger compared to other teleosts such as Astyanax bimaculatus and Tetragonopterus chalceus (Sato et al., 2003a), and the value was close to that described for other catfish species such as Pimelodus maculatus (Sato et al., 1999), Pseudopimelodus charus, and R. quelen (Sampaio \& Sato, 2006). A very thick chorion, as observed in L. alexandri, may represent a defense mechanism for the embryo against environmental adversities and may contribute to higher survival rates because this species has a relatively low fecundity. The average diameter of the yolk sac in $L$. alexandri was high compared with other catfish species; for example, the diameter was $694 \mu \mathrm{m}$ in Pimelodus maculatus (Sato et al., 1999), $1058 \mu \mathrm{m}$ in Pseudopimelodus charus, and $955 \mu \mathrm{m}$ in R. quelen (Sampaio \& Sato, 2006).

Regarding the number of oocytes in relation to the weight of the ova, L. alexandri had an average of 74 oocytes $\mathrm{g}^{-1}$, a value which is much smaller than other Siluriformes including Pseudoplatystoma corruscans (Sato et al., 2003a), Pimelodus maculatus (Sato et al., 1999), Z. jahu (Nogueira et al., 2012), T. galeatus (Santos et al., 2013), R. quelen, and Pseudopimelodus charus (Sampaio \& Sato, 2006). The low fecundity (i.e., 324 oocytes per gram of ovulated ovary mass) was also described in another Siluriformes species that was induced to spawn: the endangered Steindachneridion parahybae from the Paraíba do Sul River, Brazil (Caneppele et al., 2009). The average GSI for mature females of $L$. alexandri was $2 \%$. In general, mature females of Siluriformes species exhibit GSI values between 7 and 20\% (Sato et al., 2003b; Godinho, 2007). The maximum reported SOI (stripped ova index) for
L. alexandri was $1.4 \%$ with a mean value of $1.2 \%$. Commonly, Siluriformes species have SOI ranging from 3 to 16\% (Sato et al., 1998; Sato et al., 1999; Sampaio \& Sato, 2006).

Fecundity is an important biological variable for aquaculture, species management, and conservation, and it estimates the reproductive potential of a fish species (Godinho, 2007; Arantes et al., 2011). Migratory fish generally have high fecundities while sedentary fish release a much smaller number of eggs per spawning, which is compensated by spawning multiple times throughout the reproductive period (Godinho, 2007). The total fecundity of pacamã ranged from 3,519 to 5,467 oocytes, which was similar to the range recorded for T. galeatus (i.e., 1,505 to 4,651 oocytes, Santos et al., 2013) but was much smaller than the fecundities measured in other Neotropical catfishes: 24,640-134,176 in Pseudopimelodus charus; 16,750-79,886 in R. quelen (Sampaio \& Sato 2006); 80,120-205,206 in Pimelodus maculatus (Sato et al., 1999); 21,813 in F. marmoratus (Sato et al., 2003b); and 81,900-347,604 in Rhinelepis aspera (Sato et al., 1998).

The fertilization rate (i.e., the relative number of viable and dead embryos) is another important tool in fish farming and is important to the management and conservation of fish species (Sato et al., 2003a; Godinho, 2007). Lophiosilurus alexandri had a 59\% fertilization rate, which is similar to that obtained in other Siluriformes: $61.6 \%$ in Rhamdia sapo (= R. quelen) (Espinach Ros et al., 1984), $70.4 \%$ in Pseudoplatystoma corruscans (Sato et al., 2003a), $64.8 \%$ in Pimelodus maculatus (Sato et al., 1999), $72.4 \%$ in Rhinelepis aspera (Sato et al., 1998), 75\% in Rhamdia quelen and Pseudopimelodus charus (Sampaio \& Sato, 2006). However, Z. jahu submitted to CPH presented high fertilization rate (i.e., 92\%, Nogueira et al., 2012). In Pseudoplatystoma fasciatum, fertilization rates of approximately $53 \%$ and $56 \%$ were described for the animals' first and second gonadal maturations submitted to $\mathrm{CPH}$, respectively. In this work, the authors also reported that the fertilization rate in induced spawning using human chorionic gonadotropin (hCG) was significantly higher (i.e., approximately $82 \%$ ) than in animals treated with $\mathrm{CPH}$ in the second gonadal maturation (Leonardo et al., 2004). The initial fertility rate of L. alexandri averaged $58 \%$, and while the final fertility rate reached $34 \%$ in relation to total fecundity, these values were low compared to other Siluriformes species (Sato et al., 1998; Sato et al., 1999; Sampaio \& Sato, 2006).

Regarding larval biometry, L. alexandri larvae measured on average $8.4 \mathrm{~mm}$ in total length, which is much higher than other Siluriformes larvae $(4.0 \mathrm{~mm}$ in Rhamdia hilarii (= R. quelen); $2.6 \mathrm{~mm}$ in Pimelodus maculatus; 2.8 $3.5 \mathrm{~mm}$ in R. quelen; and $3.0 \mathrm{~mm}$ in Pseudopimelodus charus) (Godinho et al., 1978; Sato et al., 2003b; Sampaio $\&$ Sato 2006). The cement gland, or adhesive organ, is found 
on the dorsal and lateral head region of some fish larvae and is important to attach the larvae to a substrate during early development (Sato et al., 2003b; Gomes et al., 2007). In this work, the larvae of $L$. alexandri did not present a larval adhesive organ; the absence of an adhesive organ is a common feature in the larvae of some Siluriformes species (Sato et al., 2003b; Sampaio \& Sato, 2006; Santos et al., 2013).

In conclusion, the results obtained here for $L$. alexandri demonstrated the success of artificial reproduction for this species. Because there are few studies on the reproductive biology of $L$. alexandri, this work provides important biological information regarding induced spawning and reproductive variables that can be applied to aquaculture, management and conservation of this species.

\section{Acknowledgments}

We are thankful to the Estação de Hidrobiologia e Piscicultura de Três Marias and the Companhia de Desenvolvimento dos Vales do São Francisco e do Parnaíba, Três Marias, as well as CEMIG-GT for technical assistance in providing the facilities used for this study. The study was supported by grants from FAPEMIG (APQ 00837/08) and CNPq $\left(\mathrm{n}^{\circ} 482826 / 2010-0\right)$. We are also grateful to the reviewers by their commentaries and suggestions that improved the manuscript.

\section{Literature Cited}

Arantes, F. P., H. B. Santos, E. Rizzo, Y. Sato \& N. Bazzoli. 2011. Influence of water temperature on induced reproduction by hypophysation, sex steroids concentrations and final oocyte maturation of the "curimatã-pacu" Prochilodus argenteus (Pisces: Prochilodontidae). General and Comparative Endocrinology, 172: 400-408.

Barros, D. M., R. J. Guimarães-Cruz, V. C. Veloso-Júnior \& J. E. Santos. 2007. Reproductive apparatus and gametogenesis of Lophiosilurus alexandri Steindachner (Pisces, Teleostei, Siluriformes). Revista Brasileira de Zoologia, 24: 213-221.

Caneppele, D., R. M. Honji, A. W. S. Hilsdorf \& R. G. Moreira. 2009.Induced spawning of the endangered Neotropical species Steindachneridion parahybae (Siluriformes: Pimelodidae). Neotropical Ichthyology, 7: 759-762.

Cussac, V. E., M. Matkovic \& M. C. Maggese. 1985. Desarollo embrionario de Rhamdia sapo (Valenciennes, 1840) Eigenmann y Eigenmann, 1888 (Pisces, Pimelodidae) II. Organogénesis media, organogénesis tardía y eclosión. Revista Brasileira de Biologia, 45: 149-160.

Eschmeyer, W. N. \& Fong, J. D. Species by Family/Subfamily. (http://research.calacademy.org/research/ichthyology/catalog/ SpeciesByFamily.asp). Electronic version accessed 04 Jun 2013.

Espinach Ros, A., V. G. Amutio, J. P. M. Arceredillo, G. Orti \& A. Nani. 1984. Induced breeding of the South American catfish, Rhamdia sapo (C. \& V.). Aquaculture, 37: 141-146.

Godinho, H. P. 2007. Estratégias reprodutivas de peixes aplicadas à aqüicultura: bases para o desenvolvimento de tecnologias de produção. Revista Brasileira de Reprodução Animal, 31: 351-360.
Godinho, H. P., N. A. Fenerich \& M. Y. Narahara 1978. Desenvolvimento embrionário e larval de Rhamdia hilarii (Valenciennes, 1840) (Siluriformes, Pimelodidae). Revista Brasileira de Biologia, 38: 151-156.

Gomes, B. V. C., R. S. Scarpelli, F. P. Arantes, Y. Sato, N. Bazzoli \& E. Rizzo. 2007. Comparative oocyte morphology and early development in three species of trahiras from the São Francisco River basin, Brazil. Journal of Fish Biology, 70: 1412-1429.

Leonardo, A. F. G., E. Romagosa, M. I. Borella \& S. R. Batlouni. 2004. Induced spawning of hatchery-raised Brazilian catfish, cachara Pseudoplatystoma fasciatum (Linnaeus, 1766). Aquaculture, 240: 451-461.

Michalany, J. 1980. Técnica histológica em anatomia patológica, com instruções para o cirurgião, enfermeira e citotécnico. São Paulo, EPU.

Nogueira, L. B., P. G. Azevedo, M. R. Canelhas, A. G. Bedore, J. M. Lopes \& H. P. Godinho. 2012. Induced spawning and early ontogeny in hatchery-reared catfish Zungaro jahu (Siluriformes: Pimelodidae). Neotropical Ichthyology, 10: 8998.

Pereira, C. R., L. J. G. Barcellos, L. C. Kreutz, R. M. Quevedo, F. Ritter \& L. B. Silva. 2006. Embryonic and larval development of jundiá (Rhamdia quelen, Quoy \& Gaimard, 1824, Pisces, Teleostei), a South American Catfish. Brazilian Journal of Biology, 66: 1057-1063.

de Pinna, M. C. C. 1998. Phylogenetic relationships of neotropical siluriformes (Teleostei: Ostariophysi): Historical overview and synthesis of hypotheses. Pp. 279-330. In: Malabarba, L. R., R. E. Reis, R. P. Vari, Z. M. Lucena \& C. A. S. Lucena (Orgs.). Phylogeny and Classification of Neotropical Fishes. Porto Alegre, Edipucrs.

Riehl, R. \& R. A. Patzner. 1998. Mini review: the modes of egg attachment in teleost fishes. Italian Journal of Zoology, 65: 415-420.

Rizzo, E., Y. Sato, B. P. Barreto \& H. P. Godinho. 2002. Adhesiveness and surface patterns of eggs in neotropical freshwater teleosts. Journal of Fish Biology, 61: 615-632.

Sampaio, E. V. \& Y. Sato. 2006. Biologia reprodutiva e desova induzida de duas espécies de bagres (Osteichthyes: Siluriformes) da bacia do rio São Francisco. Acta Scientiarum Biological Sciences, 28: 263-268.

Santos, J. C. E. \& R. K. Luz. 2009. Effect of salinity and prey concentrations on Pseudoplatystoma corruscans, Prochilodus costatus and Lophiosilurus alexandri larviculture. Aquaculture, 287: 324-328.

Santos, H. B., F. P. Arantes, E. V. Sampaio \& Y. Sato. 2013. Artificial reproduction and reproductive parameters of the internally inseminated driftwood catfish Trachelyopterus galeatus (Siluriformes: Auchenipteridae). Ichthyological Research, 60: 142-148.

Sato, Y., N. Fenerich-Verani \& H. P. Godinho. 2003a. Reprodução induzida de peixes da bacia do São Francisco. Pp. 275-289. In: H. P. Godinho \& A. L. Godinho (Orgs.). Águas, peixes e pescadores do São Francisco das Minas Gerais. Belo Horizonte, Editora PUC Minas.

Sato, Y., N. Fenerich-Verani, A. P. O. Nuñer, H. P. Godinho \& J. R. Verani. 2003b. Padrões reprodutivos de peixes da bacia do São Francisco. Pp. 229-274. In: H. P. Godinho \& A. L. Godinho (Orgs.). Águas, peixes e pescadores do São Francisco das Minas Gerais. Belo Horizonte, Editora PUC Minas. 
Sato, Y., N. Fenerich-Verani, J. R. Verani, H. P. Godinho \& E. V. Sampaio. 1999. Reproductive aspects of the yellow-mandi catfish Pimelodus maculatus Lacépède, 1803 (Osteichthyes, Siluriformes). Revista Brasileira de Zoologia, 16: 981-986.

Sato, Y., N. Fenerich-Verani, J. R. Verani, H. P. Godinho \& E. V. Sampaio. 1998. Induced reproduction and reproductive characteristics of Rhinelepis aspera Agassiz, 1829 (Osteichthyes: Siluriformes, Loricariidae). Brazilian Archives of Biology Technology, 41: 309-314.

Sato Y., N. Fenerich-Verani, J. R. Verani, L. J. S. Vieira \& H. P. Godinho. 2000. Induced reproductive responses of the neotropical anostomid fish Leporinus elongatus Val. under captive breeding. Aquaculture Research, 31: 189-193.

Shatunovskiy, M. I. 1988. Some indices of reproductive ability of fishes. Journal of Ichthyology, 28: 119-123.

Woynarovich, E. \& L. Horvat 1980 . The artificial propagation of warm-water fin fishes - manual of extensions. FAO Fisheries Technical Paper, 201: 1-183.

Submitted November 19, 2012

Accepted May 27, 2013 by Bernardo Baldisserotto Published September 30, 2013 